\title{
CONTRIBUTIONS
}

Contributions, which may be in English, French or German, should be submitted in typescript (two copies) to Professor G. N. Stanton, King's College, Strand, London $\mathrm{WC}_{2} \mathrm{R}$ 2LS. Contributors are asked to follow the "Instructions for Contributors", NTS 34 (1988) 476-479. Each contributor will receive a copy of the number and 25 off-prints of his article free of charge. Authors will be responsible for all alterations to proofs which exceed $20 \%$ of the cost of composition.

\section{MONOGRAPH SERIES}

In view of the increasing number of typescripts which are being received for possible publication, those who wish to submit work are asked not to do so without first consulting the Editor who will be glad to advise about format, length and possible date of publication if the work can be accepted.

C) CAMBRIDGE UNIVERSITY PRESS 1990

\section{COPYING}

This journal is registered with the Copyright Clearance Center, 27 Congress St., Salem, Mass. or970. Organizations in the USA who are also registered with C.C.C. may therefore copy material (beyond the limits permitted by sections 107 and 108 of US copyright law) subject to payment to C.C.C. of the per-copy fee of $\$ 5.00$. This consent does not extend to multiple copying for promotional or commercial purposes. Code $0028-6885 / 90 \$ 5.00+.00$.

ISI Tear Sheet Service, 350 I Market Street, Philadelphia, Pennsylvania 19104, USA, is authorised to supply single copies of separate articles for private use only.

For all other use, permission should be sought from Cambridge or the American Branch of Cambridge University Press.

\section{CAMBRIDGE UNIVERSITY PRESS}

The Pitt Building, Trumpington Street, Cambridge CB2 IRP

40 West 2oth Street, New York, NY roor I, USA

Io Stamford Road, Oakleigh, Melbourne 3166, Australia 